\title{
AKTIVITAS ANTIMIKROBA EKSTRAK DAUN TURI (Sesbania grandiflora L.) TERHADAP MIKROBA Candida albicans dan Staphylococcus aureus
}

\author{
Nur Wahidah, Muhammad Amir Masruhim, Mirhansyah Ardana \\ Laboratorium Penelitian dan Pengembangan FARMAKA TROPIS Fakultas Farmasi \\ Universitas Mulawarman, Samarinda, Kalimantan Timur \\ email: nwnurwahidah@gmail.com
}

\begin{abstract}
This research has the purpose to prove the presence antimicrobial activity turi leaves. Antimicrobial activity against Staphylococcus aureus and Candida albicans. Microbial activity test performed by the agar diffusion method on a petri dish using paperdisc with a concentration of $5 \%, 10 \%, 15 \%, 20 \%, 25 \%, 30 \%$, and $35 \%$ on Staphylococcus aureus, and a concentration of 2.5\%, 5\%, $7.5 \%$ and $10 \%$ on the Candida albicans, and distilled water as a negative control. The results showed the antimicrobial activity of the leaf extract turi seen from the zone of inhibition. Best concentrations present in concentrations of $30 \%$ on Staphylococcus aureus and $5 \%$ concentration on the Candida albicans.
\end{abstract}

Keywords : $\quad$ Antimicrobial, Candida albicans, and Staphylococcus aureus.

\begin{abstract}
ABSTRAK
Penelitian ini bertujuan untuk mengetahui aktivitas daun turi sebagai antimikroba. Aktivitas antimikroba terhadap Staphylococcus aureus dan Candida albicans. Pengujian aktivitas mikroba dilakukan dengan metode difusi agar pada cawan petri menggunakan paperdisc dengan konsentrasi 5\%, 10\%, 15\%, 20\%, 25\%, 30\%, dan 35\% pada bakteri Staphylococcus aureus, dan konsentrasi 2,5\%, 5\%, 7,5\% dan 10\% pada jamur Candida albicans, dan aquades sebagai kontrol negatif. Hasil penelitian menunjukkan adanya aktivitas antimikroba ekstrak daun turi dilihat dari zona hambat. Konsentrasi terbaik terdapat pada konsentrasi 30\% pada bakteri Staphylococcus aureus, dan konsentrasi 5\% pada jamur Candida albicans.
\end{abstract}

Kata Kunci: Antimikroba, Candida albicans, dan Staphylococcus aureus.

\section{PENDAHULUAN}

Pengobatan penyakit infeksi yang disebabkan bakteri yang resisten terhadap antibiotik memerlukan produk baru yang memiliki potensi tinggi. Penelitian zat yang berkhasiat sebagai antibakteri perlu dilakukan untuk menemukan produk antibiotik baru yang berpotensi untuk menghambat atau membunuh bakteri yang resisten antibiotik dengan harga yang terjangkau. Salah satu alternatif yang dapat ditempuh adalah memanfaatkan zat aktif pembunuh bakteri yang terkandung dalam tanaman obat (Fitriyah, 2013).

Salah satu tanaman yang dimanfaatkan yaitu turi (Sesbania grandifora L.). Bagian tanaman yang digunakan sebagai obat ialah bunga, daun dan kulit batang. Bagian daun turi sendiri sering digunakan sebagai obat pereda nyeri, luka dan keputihan. Menurut 
Dalimartha (2009), daun turi mengandung saponin, tanin, glikoside, peroksidase, vitamin A dan B, serta berkhasiat mencairkan bekuan darah, meredakan nyeri, pencahar ringan, dan meluruhkan kencing (diuretik). Menurut Widyaningrum (2011), daun turi berkhasiat untuk mengobati keseleo, memar akibat terpukul (hematoma), luka, keputihan (fluor albus), batuk, hidung berlendir, sakit kepala, memperbanyak produksi asi, beri-beri, demam nifas, dan radang tenggorokan. Dari kandungan tanin dan saponin, serta khasiat pada daun turi sebagai obat luka dan keputihan, maka dilakukan pengujian aktivitas antimikroba dari bagian daun tanaman turi tersebut.

Menurut Sarwono (2008) dalam jurnal ilmiah kebidanan, keputihan adalah semua pengeluaran cairan alat genetalia yang bukan darah. Salah satu penyebab keputihan ialah jamur Candida albicans. Umumnya dipicu oleh faktor luar dan dalam tubuh seperti kehamilan, kegemukan, pemakaian pil KB, obat-obatan tertentu seperti steroid, daya tahan tubuh yang rendah, iklim panas atau lembab. Menurut latuheru (2013), luka adalah hilang atau rusaknya sebagian jaringan tubuh. Keadaan ini dapat disebabkan oleh trauma, benda tajam atau tumpul, perubahan suhu, zat kimia, atau gigitan hewan. Luka tidak dapat dibiarkan sembuh sendiri karena jika luka tidak dirawat dapat menyebabkan komplikasi penyembuhan luka yaitu dapat terjadi infeksi dan pendarahan. Infeksi pada luka dapat terjadi jika luka terkontaminasi oleh debu atau bakteri, hal ini disebabkan karena luka tidak dirawat dengan baik. Bakteri yang biasanya menyebabkan infeksi pada luka ialah Staphylococcus aureus.

\section{METODE PENELITIAN}

\section{Bahan}

Bahan sampel yang digunakan dalam penelitian ini adalah daun turi. Pelarut yang digunakan untuk maserasi adalah etanol 70\%. Bahan lainnya adalah medium NA (Nutrien Agar), medium PDA (Potato Dextrose Agar) dan air suling. Mikroba uji yang digunakan ialah Candida albicans dan Staphylococcus aureus.

\section{Peralatan}

Peralatan yang digunakan dalam penelitian adalah wadah maserasi, rotary evaporator, timbangan analitik, labu ukur $5 \mathrm{~mL} ; 10 \mathrm{~mL}$, cawan porselin, tabung reaksi, cawan petri, autoklaf, LAF (Laminar Air Flow), inkubator dan mikropipet 100-1000 $\mu$ L.

\section{PROSEDUR PENELITIAN}

\section{Pengumpulan Sampel}

Daun turi diperoleh di daerah Samarinda. Daun turi yang telah dikumpulkan kemudian disortasi basah dan ditimbang. Selanjutnya dibersihkan dengan air yang mengalir, kemudian dikeringkan dengan cara diangin-anginkan di dalam ruangan yang tidak terpapar langsung sinar matahari hingga diperoleh daun kering. Daun yang telah kering kemudian disortasi kering dan ditimbang.

\section{Pembuatan Ekstrak}

Ekstrak daun turi dibuat dengan cara maserasi. Sebanyak 123 gram simplisia daun turi dimasukkan ke dalam wadah maserasi, kemudian direndam dengan larutan etanol $70 \%$ sebanyak 2 Liter dan dibiarkan selama 3 hari sambil sesekali diaduk. Setelah 3 hari, sampel yang direndam kemudian disaring. Hasil maserasi yang diperoleh kemudian dievaporasi menggunakan rotary evaporator, sehingga diperoleh ekstrak kental daun turi. 


\section{Persiapan Mikroba Uji}

Bakteri Staphylococcus aureus ditanam pada medium NA dan diinkubasi selama $1 \times 24$ jam dengan suhu $37^{\circ} \mathrm{C}$. Jamur Candida albicans ditanam pada medium PDA dan diinkubasi selama $2 \times 24$ jam dengan suhu ruang. Kemudian dibuat suspensi dengan menggunakan $\mathrm{NaCl}$ 0,9\% pada pengenceran 1:40 untuk bakteri dan pengenceran 1:10 untuk jamur.

\section{Pengujian Aktivitas Antimikroba}

Pengujian aktivitas antimikroba ekstrak daun turi dilakukan dengan metode difusi agar menggunakan paper disk. Suspense mikroba sebanyak 0,02 $\mathrm{mL}$ dan medium NA sebanyak $10 \mathrm{~mL}$ untuk bakteri, medium PDA sebanyak $10 \mathrm{ml}$ untuk jamur dimasukkan ke dalam cawan petri dengan metode tuang. Paper disk direndam dalam ekstrak daun turi, kontrol negatifnya menggunakan aquades. Kemudian diinkubasi selama 1x24 jam dengan suhu $37^{\circ} \mathrm{C}$ untuk bakteri dan diinkubasi selama $2 \times 24$ jam dengan suhu ruang untuk jamur.

\section{HASIL DAN PEMBAHASAN}

Pengujian aktivitas antimikroba ekstrak daun turi terhadap bakteri Staphylococcus aureus menggunakan konsentrasi 5\%, 10\%, 15\%, 20\%, 25\%, 30\%, dan 35\%. Sedangkan terhadap jamur Candida albicans menggunakan konsentrasi 2,5\%, 5\%, 7,5\% dan $10 \%$. Hasil yang diperoleh dapat dilihat pada Gambar 1 dan Gambar 2.
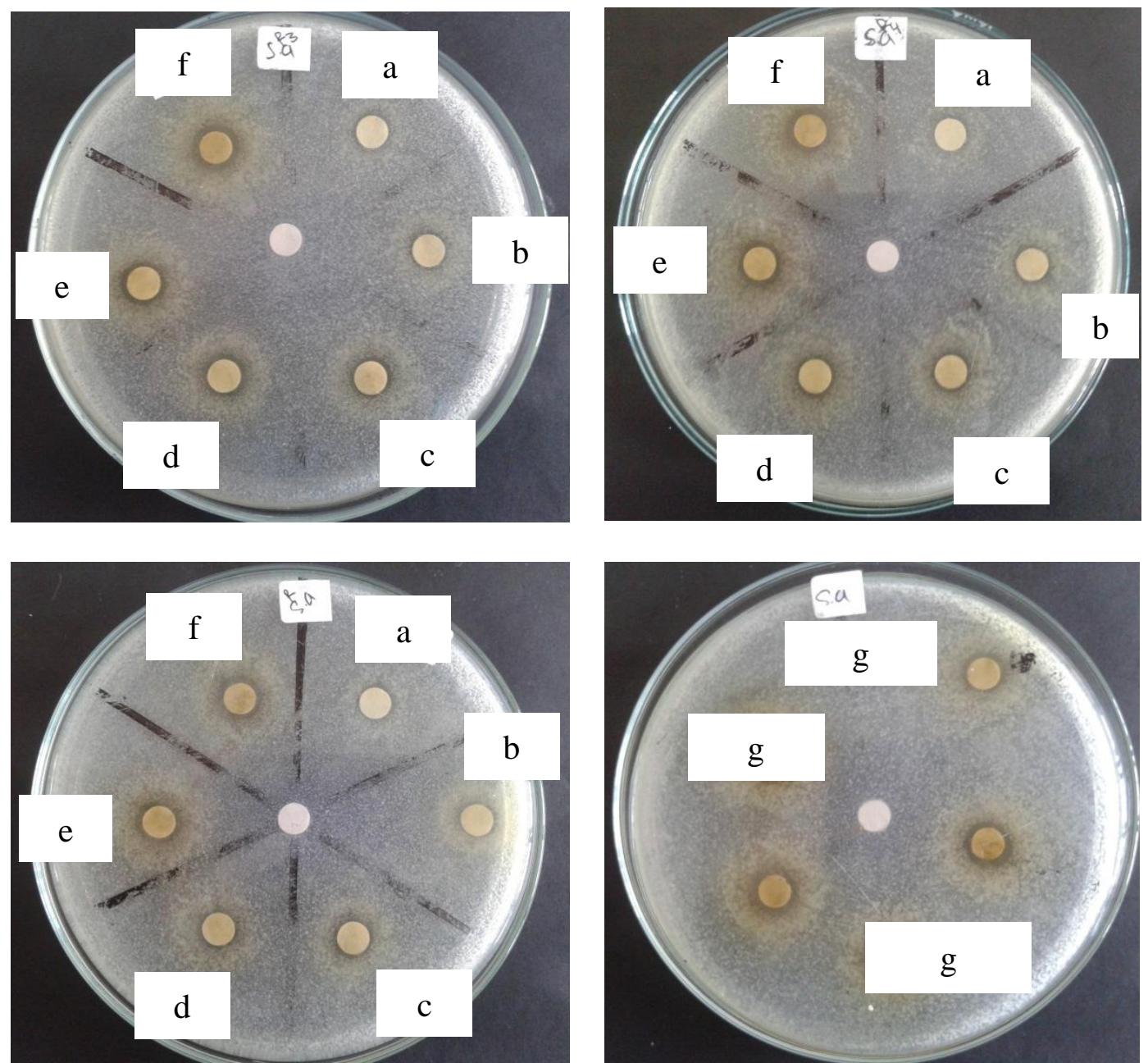

Gambar 1. Aktivitas antimikroba ekstrak daun turi terhadap bakteri Staphylococcus aureus, $=5 \%, \mathrm{~b}=10 \%, \mathrm{c}=15 \%, \mathrm{~d}=20 \%, \mathrm{e}=25 \%, \mathrm{f}=30 \%, \mathrm{~g}=35 \%$ 

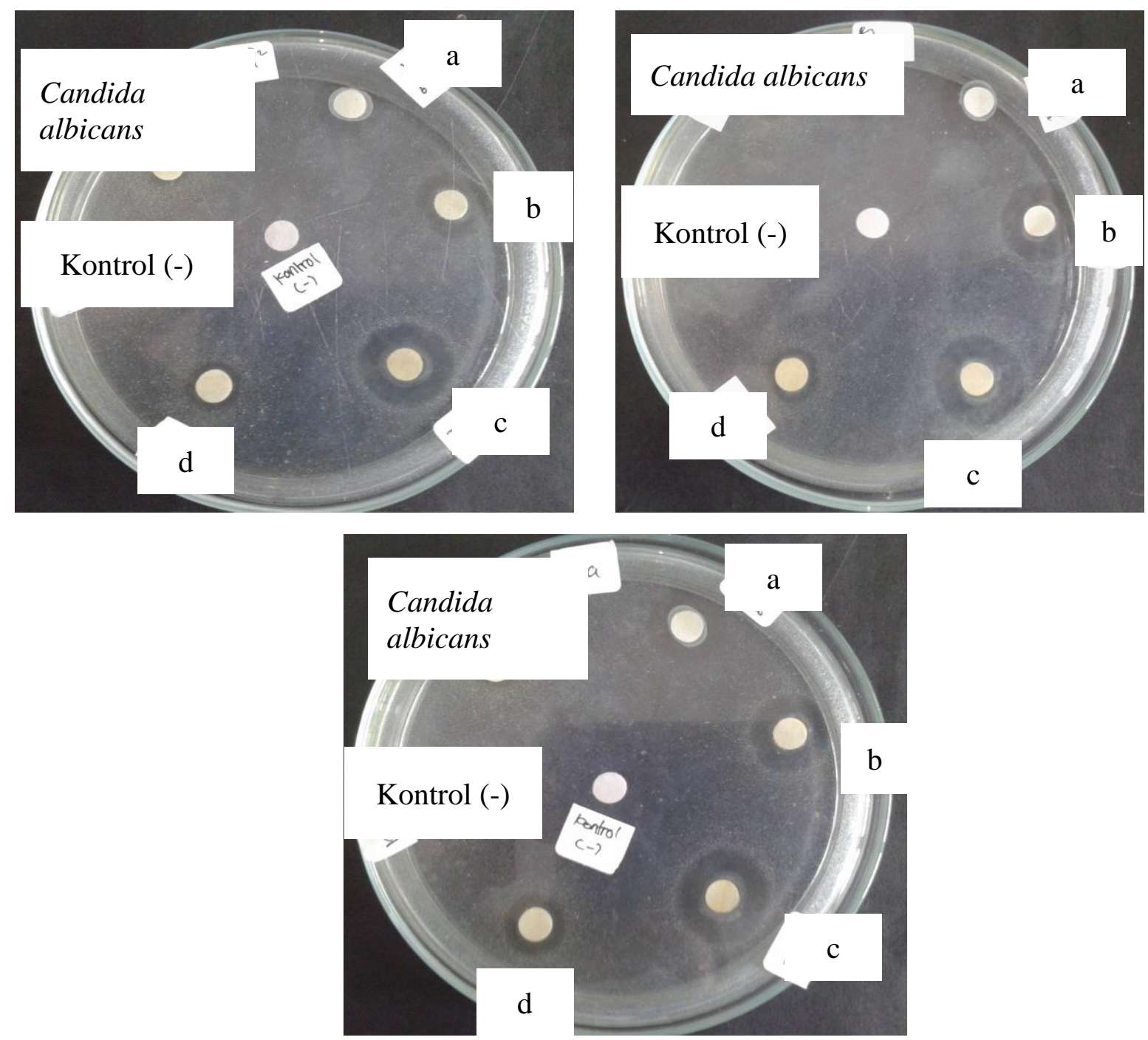

Gambar 2. Aktivitas antimikroba ekstrak daun turi terhadap jamur Candida albicans, $\mathrm{a}=$ $2,5 \%, b=5 \%, c=10 \%, d=15 \%$

Gambar 1 dan Gambar 2 menunjukkan adanya aktivitas antimikroba ekstrak daun turi yang dapat dilihat terbentuknya zona hambat pada bakteri dan zona bunuh pada jamur. Dibandingkan dengan kontrol negative berupa aquades yang digunakan untuk melarutkan ekstrak tidak terbentuk zona hambat ataupun zona bunuh. Hal ini menyatakan bahwa zona hambat atau zona bunuh yang terbentuk tidak dipengaruhi oleh pelarut ekstrak, tetapi dari ekstrak daun turi.

Diameter zona hambat ataupun zona bunuh dari aktivitas antimikroba ekstrak daun turi dapat dilihat pada tabel 1 dan tabel 2. 
Tabel 1. Hasil pengujian aktivitas antimikroba ekstrak daun turi terhadap bakteri Staphylococcus aureus

\begin{tabular}{cccc}
\hline \multirow{2}{*}{ Bakteri uji } & \multirow{2}{*}{ Konsentrasi } & \multicolumn{2}{c}{ Rerata Diameter (mm) } \\
\cline { 3 - 4 } & $5 \%$ & Zona hambat & Zona bunuh \\
\hline \multirow{3}{*}{ Staphylococcus } & $10 \%$ & 0,948 & - \\
aureus & $15 \%$ & 1,289 & - \\
& $20 \%$ & 1,464 & - \\
& $25 \%$ & 1,542 & - \\
& $30 \%$ & 1,865 & - \\
& $35 \%$ & 2,620 & - \\
\hline
\end{tabular}

Aquades

Keterangan : * = hasil rata-rata tiga replikasi pengujian, - = tidak ada zona hambat/zona bunuh

Tabel 2. Hasil pengujian aktivitas antimikroba ekstrak daun turi terhadap jamur Candida albicans

\begin{tabular}{cccc}
\hline \multirow{2}{*}{ Jamur uji } & \multirow{2}{*}{ Konsentrasi } & \multicolumn{2}{c}{ Rerata Diameter (mm)* } \\
\cline { 3 - 4 } & & Zona hambat & Zona bunuh \\
\hline \multirow{3}{*}{ Candida albicans } & $2,5 \%$ & - & 6,754 \\
& $5 \%$ & - & 8,262 \\
& $7,5 \%$ & - & 8,827 \\
Aquades & $10 \%$ & - & 6,362 \\
\hline
\end{tabular}

Keterangan : $*=$ hasil rata-rata tiga replikasi pengujian, - = tidak ada zona hambat/zona bunuh

Aktivitas antimikroba ekstrak daun turi terhadap bakteri Staphylococcus aureus dan jamur Candida albicans dapat disebabkan oleh adanya metabolit sekunder seperti tanin, flavonoid dan saponin. Tanin mengkoagulasi protein dinding sel sehingga aktivitas bakterisida dalam konsentrasi tinggi, sedangkan saponin mengubah permeabilitas dinding sel sehingga memudahkan masuknya bahan beracun atau merusak konstituen penting dari sel. Flavonoid merupakan fenolik di alam, bertindak sebagai racun pada sitoplasma yang menghambat aktivitas enzim (oyi, 2007).

Konsentrasi terbaik ekstrak daun turi sebagai antimikroba dari data diameter zona hambat atau zona bunuh dengan menggunakan uji Anava satu arah. Kemudian dilanjutkan dengan uji Tukey HSD (Honestly Significant Diference) menggunakan program SPSS (Statistical Product of Service Solution) Statistics 21.

Hasil uji beda nyata lanjutan (Tukey) untuk pengujian bakteri Staphylococcus aureus dengan konsentrasi yang berbeda menunjukkan bahwa terdapat perbedaan yang sangat nyata (signifikan) terhadap tiap perlakuan. Hasil konsentrasi terbaik menunjukkan bahwa konsentrasi terbaik ekstrak daun turi sebagai antimikroba terhadap bakteri Staphylococcus aureus ialah $30 \%$. Karena pada konsentrasi $30 \%$ merupakan konsentrasi yang memberikan kemampuan terbaik dalam menghambat bakteri Staphylococcus aureus dibandingkan dengan konsentrasi lainnya. 


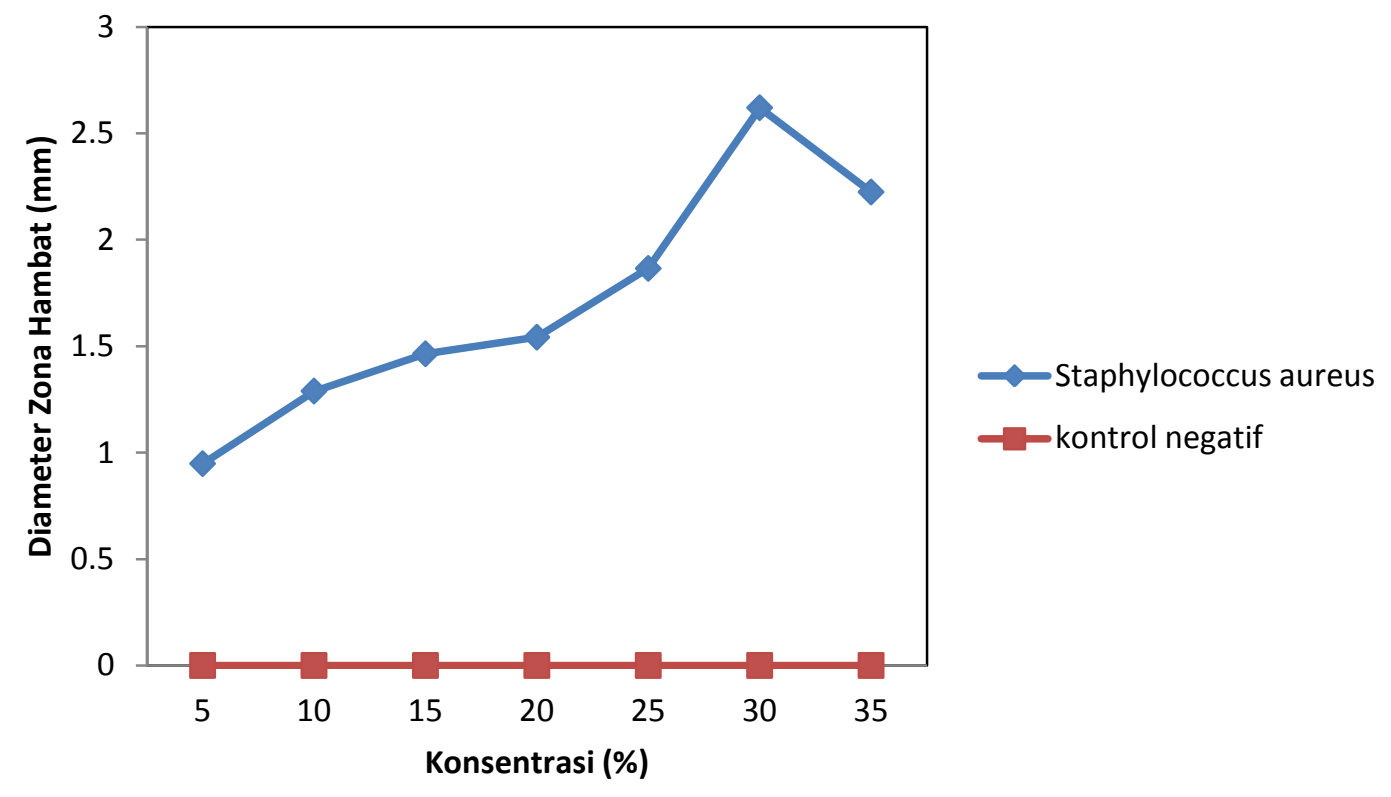

Gambar 3. Grafik diameter zona hambat ekstrak daun turi terhadap bakteri Staphylococcus aureus

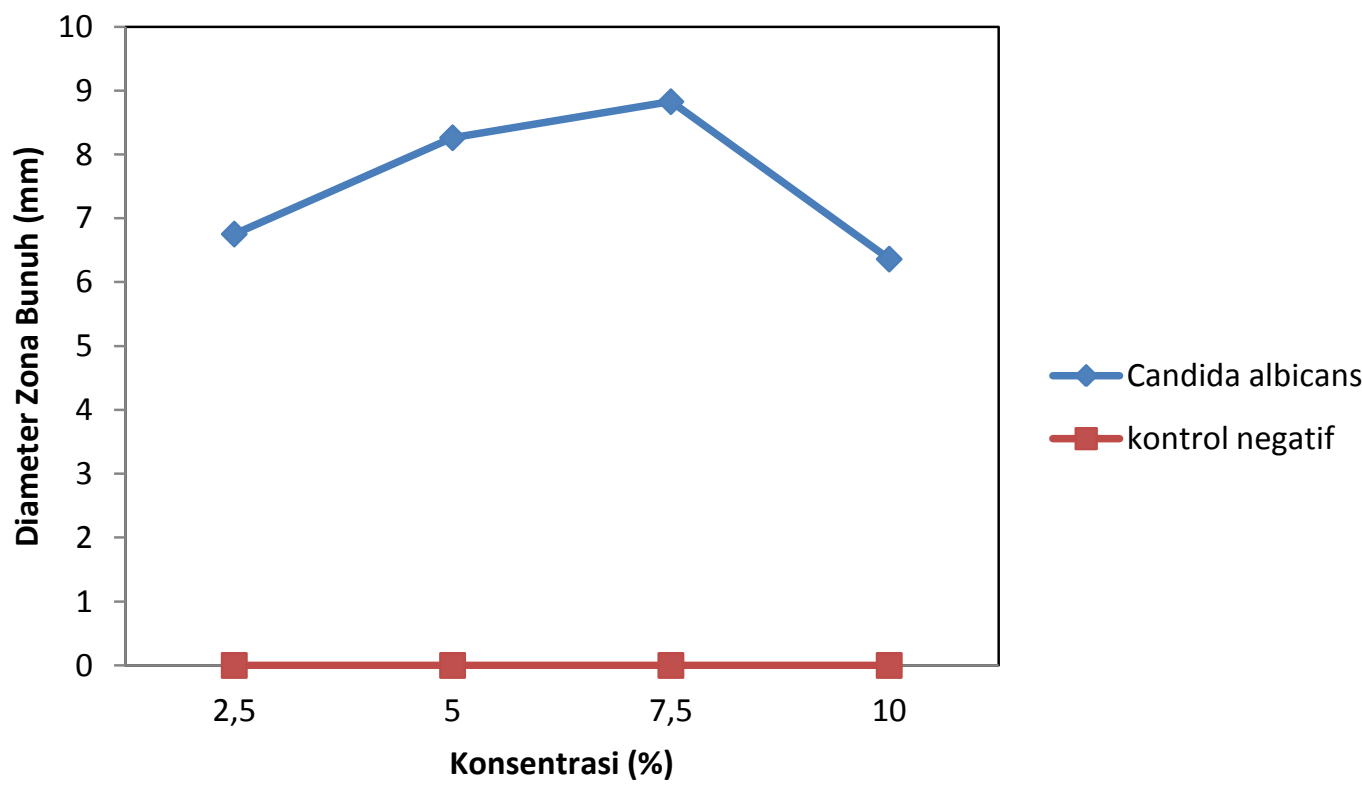

Gambar 4. Grafik diameter zona bunuh ekstrak daun turi terhadap jamur Candida albicans

Hasil uji beda nyata lanjutan (Tukey) untuk pengujian jamur Candida albicans dengan konsentrasi yang berbeda menunjukkan bahwa terdapat perbedaan yang sangat nyata (signifikan) terhadap tiap perlakuan. Hasil konsentrasi terbaik menunjukkan bahwa konsentrasi terbaik ekstrak daun turi sebagai antimikroba terhadap jamur Candida albicans ialah 5\%. Dilihat dari grafik konsentrasi terbaik adalah 7,5\%, dimana dalam uji beda nyata lanjutan (Tukey) konsentrasi 5\% dengan 7,5\% menunjukkan hasil yang tidak berbeda 
nyata (non signifikan) dan diinginkan konsentrasi terendah yang dapat membunuh seluruh pertumbuhan bakteri, sehingga konsentrasi yang terbaik ialah konsentrasi 5\%.

Konsentrasi ekstrak yang berbeda menimbulkan zona hambat atau zona bunuh yang berbeda pula. Zona hambat ekstrak daun turi terhadap bakteri Staphylococcus aureus pada konsentrasi $30 \%$ memiliki diameter zona hambat terbesar kemudian pada konsentrasi $35 \%$ menurun, begitu pula dengan zona bunuh ekstrak daun turi terhadap jamur pada konsentrasi $10 \%$ diameter rata-rata zona bunuh menurun. Hal ini dapat disebabkan konsistensi bahan ekstrak sudah hampir padat dan tingkat kelarutan dari ekstrak yang menurun sehingga zat aktif yang terdapat dalam konsentrasi tersebut tidak efektif berdifusi ke dalam agar sehingga didapatkan hasil daya hambat yang kurang atau menurun di konsentrasi tertinggi (Putra, 2015). Menurut Sarjono (2007), dengan variasi konsentrasi yang digunakan, aktivitas antimikroba awalnya akan meningkat sampai maksimal pada konsentrasi tertentu, setelah diperoleh hambatan maksimal aktivitasnya akan turun dan cenderung konstan.

\section{KESIMPULAN}

Ekstrak daun turi memiliki aktivitas antimikroba, terlihat dari zona hambat yang terbentuk. Konsentrasi terbaik terdapat pada konsentrasi 30\% pada bakteri Staphylococcus aureus, dan konsentrasi 5\% pada jamur Candida albicans.

\section{DAFTAR PUSTAKA}

1. Dalimartha, Setiawan. 2000. Atlas Tumbuhan Obat Indonesia Jilid 2. PT. Pustaka Pembangunan Swadaya Nusantara: Jakarta.

2. Fitriyah, Nikmatul, Mahendra Purwa K, M. Alif Alfiyanto, Mulyadi, Nila Wahuningsih, dan Joko Kismanto. 2013. Obat Herbal Antibakteri Tanaman Binahong. Jurnal KesMaDaSka hal 117-118. Surakarta.

3. Latuheru, Jean O, Jane Tambajong W dan Jimmy Posangi. 2013. Efek Daun Sirih (Piper betle L.) terhadap Penyembuhan Luka Insisi Kulit Kelinci (Oryctolagus cuniculus). Jurnal e-Biomedik (eBM) volume 1 nomor 2 hal 802-805.

4. Oyi, A.R., Onaolapo J.A., Haruna A.K. dan Morah C.O. (2007). Antimicrobial screening and stability studies of the crude extract of Jatropha curcass Linn. Latex (Euphorbiaceae). Nigerian Journal of Pharmaceutical Science 6(2): 14-20.

5. Triyani, Risna dan Ardiani S. 2013. Hubungan Pemakaian Pembersih Vagina dengan Kejadian Keputihan pada Remaja Putri. Jurnal Ilmiah Kebidanan vol.4 no.1 hal 2-4.

6. Widyaningrum, Herlia dan Tim Solusi Alternatif. 2011. Kitab Tanaman Obat Nusantara. Yogyakarta: Media Pressindo.

7. Sarjono, Purbowatiningrum R. dan Nies S Mulyani. 2007. Aktivitas Antibakteri Rimpang Temu Putih (Curcuma manga Vall). Jurnal Sains \& Matematika (JSM) Volume 15, Nomor 2 hal 91-92.

8. Putra, Ikhsan Amanda, Erly dan Machdawaty Masri. 2015. Uji Efek Antibakteri Ekstrak Etanol Kulit Batang Salam (Syzigium polyanthum (Wight) Walp) terhadap Staphylococcus aureus dan Escherichia coli secara invitro. Jurnal Kesehatan Andalas; 4(2) hal 500. 